\title{
The Land Reform of 1919-1940: Lithuania and the Countries of Eastern and Central Europe
}

\section{Gediminas VASKELA}

The Land Reform of 1919-1940 (often referred to as the reform of 1922-1940 or just 1922) has received extremely broad coverage in Lithuania. However, as is often the case, it is mainly the most concrete subjects that have been discussed, based solely on Lithuanian material. This is not to say that no effort has been made to relate it to ongoing processes in the wider region, or that comparison with other states was deliberately avoided. Yet clearly until now more detailed research has not been pursued. Nevertheless, Lithuanian government officials as well as agricultural specialists (often one and the same person) kept a close eye on the agricultural policies of their neighbours in nearby countries and also further abroad.

There is no doubt that this lack of detailed studies is due largely to the generally restricted outlook of the specialists in agrarian history (with some exceptions), who worked in Lithuania after 1940. However, this is not the only reason. It is also true that before 1940 there were hardly any attempts to go further in this direction. It still remains to account for this situation and to try and fill the obvious gaps in historiography. However, certain the basic points can ahead be discussed.

In the aftermath of World War I the refurbishment of the agrarian infrastructure was a major concern in Eastern Europe, in the newly created states. During 1918-1922 nearly all the countries in the region passed land reform acts and started to implement them.

The earliest attempts on land reform appeared in Romania and Yugoslavia. An amendment to Article 19 of the Romanian Constitution was made in Bucharest on April 19, 1917, stipulating the possibility, should public necessity arise, of expropriating and redistributing land. By the decree of December 29, 1918, of the total 2,224,588 ha, mostly held by landowners, was nationalised and distributed to peasants (with the right of disposal). The land parameters were specified by the bill of July 17,1919 . Land belonging to foreigners as well as land owned by the State and the Land Bank was transformed to the state Land Fund. Other owners were allowed to own a maximum of 100 ha. It is true now, exeptions were also made. Landowners who depended on farming as their chief means of support were allowed to keep 250 ha each (in Bessarabia - 100 ha, in Transilvania - 287,5 ha) ${ }^{1}$.

${ }^{1}$ Istoria Romāniei in date, Bucarest, 1971, 313, 323; W. Góra, Reformy agrame w europejskich państwach demokracji ludowej: 1944-1948, Warszawa, 1973, 23. 
On November 26, 1918, Yugoslavia began to distribut land in the former territories of Austro-Hungary. The royal manifesto of January 6, 1919 pledged to supply each peasant with his own land. Under the "Provisional Rules of Land Reform", passed on February 27,1919 the land of those whose property exceeded from 57.5 to 287.5 ha was re-allocated to peasants for temporary use. The decree of July 21,1919 , set up the state land fund, specifying where it was to gain and distribute land. On May 20, 1922, new differentiated maxima for land were set: in Dalmatia, Istria, Herzegovina - 50 ha of landed property or 100 ha of total land, in most of Slovenia and part of Croatia - 150 or 450 ha, in Bosnian Slovenia - 200 or 450 ha, in the new territories of Serbia and Slovenia - 300 or $500 \mathrm{ha}^{3}$.

In Czechoslovakia a land reform act was passed on April 16, 1919. In order to implement this reform, the land of those farmers who held more than 150 ha of cultivated land or 250 ha in total was expropriated ${ }^{4}$.

The Polish Sejm passed a basic land reform act on July 10, 1919. It declared the redistribution of land owned by big landlords. A year later, on July 15, 1920, a decree on implementing the reform was passed. Under this decree the maximum size of a farm allowed to remain in private hands was 150 ha of arable land. True, a number of exceptions were made. A far bigger acreage of land was left to the landowners in the western region (former German territories) and the eastern palatinates: there the maximum equalled 400 ha of total land. A declaration was made to the effect that $80 \%$ of the land under redistribution would be allotted to landless peasants and peasants with very little land, and $20 \%$ was reserved for the establishment of larger farmsteads. The decree on implementation of the land reform, passed by the Sejm on December 28, 1925, ruled that farmsteads in excess of 180 ha were to be parcelled out. The maximum of unexpropriated land in the southern and western palatinates, also Volynia, was 300 ha. The aforementioned decree also stipulated the expropriation of woods larger than 30 ha (in eastern palatinates - 50 ha) and fisheries of over $3 \mathrm{ha}^{5}$.

In the Bulgarian National Assembly land reform bills were passed on June 30, 1920 and June 25, 1921. These determined the maximum of landed property - 30 ha in the lowlands, 20 ha in mountain valleys and 50 ha in mountains. But this was only the cases owners

${ }^{2}$ S.Lovrenović, Ekonomska politika Jugoslavije, Sarajevo, 1956, 35. "Provisional regulations"... were in force till 1931 when the final statement of land reform was passed. However, the process of reform lasted till 1941.W.Szulc, Przemiany gospodarcze $i$ spoteczne $w$ Jugoslawii w okresie międzywojennym: (1918-1941), Poznań, 1980, 80, 83.

${ }^{3}$ Istorija Jugoslavije, Belgrade, 1973, 422; S. Lovrenović, op. cit., 35-36; W. Szulc, op. cit., 79-80, 82, 84 .

${ }^{4}$ R. Antons, Agraarsuchted kodanlikus Eestis, Tallinn, 1957, 33; W. Góra, op. cit., 40; Ekonomicheskaja istorija SSSR i zanubezhnyh stran, Moskva, 1978, 471. 23-25.

5. Ciepielewski, Polityka agrama rzqdu polskiego w latach 1929-1935, Warszawa, 1968, 
and members of their family who did manual labour on the farmstead. In other cases just 4 (without a family) or 10 ha were left. The land of bigger farmsteads, monasteries, different institutions and organisations was placed into the state Land Fund ${ }^{6}$.

In Finland, land reform was launched as early as October 1918 , yet the reform bill was passed only in 1922. A commitment was made to have two types of farms: small holdings (under 2 ha of cultivated land), that would serve as home farms for rural artisans and workers, and farmsteads with around 20 ha of cultivated land and a similar amount of meadows and pastures, that would constitute the basis of the country's commercial agriculture. Farm land in excess of 200 ha was redeemed by the state. These areas as well as part of free and state-owned land comprised a special fund. Those who wished to have land could buy it from the fund until $1937^{7}$.

In Hungary, the bill "On the Provision of Land for Landless Peasants and those with Little Land" was passed in 1920. True, here the state neither set the limits of big land-ownership, nor did it expropriate the land of the large estates (unlike most of East European states) nor reclaim it through an individual agreement (as in Finland). Only some of the right to acquire plots of land. In addition, owners with this right were supposed to redeem these plots at full market value from the former owner, in accordance with a direct agreement. Unless a mutual agreement was reached, the issue would be resolved in a court of law. It is obvious that this kind of restructuring is essentially different from that discussed earlier. In any event, in Hungary, as elsewhere in Eastern Europe, during the interwar period large tracts of land were redistributed ${ }^{8}$.

Land reform work was carried out even in Germany. The estates of landed nobility (land and forest possessions as well as other property) were confiscated here in 1918. In the referendum of June 20,1926 , the majority spoke in favour of paying the nobility compensation, but without returning their property. Part of the land was later redistributed among the peasantry. But this was just an episode. The authorities sought to increase the population density of the eastern areas that were dominated by Junker farmsteads. The state bought up and put in order certain estates that afterwards were sold or passed to new settlers at a discount. The Junkers themselves were interested in selling part of their land, as they were heavily in debt. 79,300 new

${ }^{6}$ Ikonomika na Blgarija. I: Ikonomikata na Blgarija do socialisticheskata revoliucija, Sofia, 1969, 484; II: Ikonomikata na Blagarija prez prehonija period ot kapitalizma km socializma, Sofia, 1972, 245; W. Góra, op. cit., 14.

${ }^{7}$ B.J. Kaslas, The Baltic nations. The question for regional integration and political liberty: Estonia, Latvia, Lithuania, Finland, Poland, Pittson, Pensylvania, 1976, 30; Lietuviu enciklopedija, XXIX, Boston, 1963, 198; XXXV, Boston, 1966, 244; Lietuviškoji Tarybinè Enciklopedija, X, Vilnius, 1983, 476.

${ }^{8}$ W. Góra, op. cit., 29; W. Schneefuss, Ungarn, Leipzig, 1939, 144; A.I. Pushkash, Bor'ba za agramyje preobrazovanija v Vengrii: (1944-1948 g.g.), Moskva, 1959, 21. 
farmsteads were established in Germany between 1919 and 1940, 193,000 families obtained extra land (a total of 1,256,200 ha) ${ }^{9}$.

As far as Lithuania's closest neighbours are concerned, a land reform bill was passed in Estonia first. On October 10, 1919 the Constituent Assembly proclaimed the expropriation of nearly 2,346,000 ha of land or $96.6 \%$ of the large estates ${ }^{10}$. The live-stock and the agricultural equipment, as well as the buildings, owned by estates, were also placed at the disposal of the state ${ }^{11}$. By the decree of October 25, 1919 , the landlord families were allowed to keep no more than 50 ha $\mathrm{each}^{12}$. Somewhat later a special decree on land exploitation in the Petser and Narva border territories was issued ${ }^{13}$. By December 10, 1919, all the major measures of land reform had been adopted in Estonia, although the revision and supplementing of individual articles continued until $1924^{14}$.

Unlike what is generally assumed in Lithuania, land reform in Estonia did not involve those farmsteads where the owners were not landlords, irrespective of the size of land. Neither did it affect intensive, the so called model farms, although the majority of these were over $100 \mathrm{ha}^{15}$ in size.

The issue of compensation for land expropriated from landlords was initially delayed in Estonia. Later, on March 5, 1926, a special decree was passed under which the land of landlords had to be paid for at a "real" price ${ }^{16}$. On February 11 of the same year a decree on the organization of church lands was passed ${ }^{17}$. By these acts land reform regulations were slightly moderated. Former landowners recovered their farm-houses and part of their holdings. The Church also regained some of its land. A decision was made to pay 12,829,000 Estonian kroons (Ekr.) as in compensation for 1023 land expropriated from and 2,891,000 Ecr. confiscated for equipment. Compensation for Church land were obliged to assume the landlords' debts - a total of $66.4 \mathrm{mln}$ golden roubles ${ }^{18}$.

${ }^{9}$ W. Góra, op. cit., 46, 48, 50; Lietuvių Enciklopedija, XXXV, 245; V. Ruge, Germania v 1917-1933g.g.: Ot Velikoi Oktiabrskoi revoliucii do konca Veimarskoi respubliki, Moskva, 1974, 194-195, 241, 252.

${ }^{10}$ Eesti pöllumajandus: Statistiline album, 3, Tallinn, 1928, 4; R. Antons, op. cit., 41.

${ }^{11}$ A. Liebman, Eestimaa Kommunistliku partei loomise ajaloost: (Veebruar 1920-aprill 1922), Tallinn, 1960, 21

${ }^{12}$ Eesti pōllumajandus, 3, 1928, 4; R. Antons, op. cit., 41; Ō. Elango, Eesti kapitalismi ajutise, ebakindla stabisatsiooni aastail (1925-1929), Tallinn, 1958, 46. Formally speaking, the Estonian constituent assembly set that farms including over 50 ha are untouchable. If a farm was over 50 ha the surplus would be expropriated leaving to the family up to 80 ha. Actually, in most cases 50 ha were left.

${ }^{13} \mathrm{R}$. Antons, op. cit., 41.

${ }^{14}$ Ibid., 63.

${ }^{15}$ Ibid., 40-42; H. Saarniit, Kodanlik Eesti sōjajängse revolutsioonilise krïisi aastail (19201924), Tallinn, 1958, 53.

${ }^{16}$ Die Republik Eesti (Estland), Tallinn, 1926, 11; Eesti pōllumajandus, 3, 1928, 4.

${ }^{17}$ Eesti pōllumajandus, 3, 1928, 4.

${ }^{18}$ R. Antons, op. cit., 63-64; Ō. Elango, op. cit., 46-49. 
The Constituent Assembly of Latvia passed a land expropriation act on September 16, 1920. The first section on the land reform act proclaimed that land owned by landlords was to be confiscated without any compensation, yet the possibility of paying some compensation in the future was not excluded. As in Estonia, landlords were allowed a norm of 50 ha of unexpropriated land, and a pledge was also made to pay their debts ${ }^{19}$. The second part of the reform bill, dealing with the distribution of expropriated land, was passed on December 21,1920 , and the third on May $3,1923^{20}$. The decree on compensation for landowners was passed only on April 14, 1924, since the majority of voters in the referendum of January 15, 1924 supported the proposal of the Social Democrats not to pay any compensation to landlords ${ }^{21}$.

The norm of unexpropriated land which in Latvia was equal to 50 ha did not mean in the least that all farms of over 50 ha were subject to expropriation. According to the bill, the land of those farms that were bigger than 100 ha was confiscated. The amount of land left to the landlords was really 50 ha, yet other citizens were permitted to keep farms of 100 ha. The state Land Fund did not include the lands that Latvian citizens had acquired before April 23, 1915, unless they were over 100 ha. On the other hand, the Latgalian hamlets (mainly the homesteads of Polish landowners), model and stock-breeding farms, and different land plots earlier sold to the peasants etc. were not expropriated. In fact, even Latvian farms of over 100 ha were not confiscated $^{22}$. In Latvia, as in Estonia, German landowners were strictly distinguished from Latvian ones.

Under the bill, land expropriation in Latvia was combined with the distribution of the local estate equipment to the new settlers, yet with certain reservations. Equipment was not confiscated if the former owner further continued farming; if the new settler acquired land elsewhere than on the estate where he lived, he would usually get no equipment ${ }^{23}$.

Despite the decision of the Parliament not to pay landlords any compensation for their expropriated land, in 1926-1927 certain landowners - citizens of France, Great Britain, Italy, Switzerland, Austria and Finland - did receive compensation. True, these were not many such in Latvia. On February 12, 1929, a secret agreement was signed with Poland, under which the Latvian government pledged to pay for 250,000 ha of land expropriated from Polish landowners ${ }^{24}$.

${ }^{19}$ A. Svikis, Agrārais jautäjums buržuāziskaja Latvijā (1920-1934), Rīga, 1960, 52, 67;

E. Žagars, Sociālistiskie pārveidojumi Latvijā: 1940-1941, Rïga, 1975, 110.

${ }^{20} \mathrm{~A}$. Svikis, op. cit., 56-57.

${ }^{21}$ Ibid., 58-59.

${ }^{22}$ Latvijas PSR vēsture, III: No 1917 gada tèdz 1950 gadam, Rìga, 1959, 210; A.Svikis, op. cit., 52, 67, 73; E. Žagars, op. cit., 110; S.Udachin, Zemelnaja reforma v Sovetskoj Latvii, Riga, 1948, 48.

${ }^{23}$ A. Svikis, op. cit., 67.

${ }^{24}$ Ibid., 135; E. Žagars, op. cit., 110. 
The population of the Lithuanian state which was established after heavy fighting was dominated by the peasantry, while a significant part of the land and strong political influence were in the hands of landowners. As the government sought to stabilise the country's political and economic situation, the land reform naturally became a major issue which everybody understood. There were few who doubted the necessity and the political, social and economic expediency of such a reform for Lithuania during the first years of independence.

In 1919 landlords in Lithuania owned nearly 1,384,000 ha of land or $26.2 \%$ of the entire state territory ${ }^{25}$. Other Eastern European countries which were similar to Lithuania in this respect include Poland, where in 1921 landlords owned $30.35 \%$ of the territory ${ }^{26}$, and Czechoslovakia, where $29 \%$ of the territory belonged to landlords ${ }^{27}$. Average estate size in Lithuania was $490 \mathrm{ha}^{28}$. Compared with its closest neighbours, in Lithuania landlord ownership was smaller and the estates far smaller. At that time landlords in Estonia owned $46.93 \%$ of the territory ${ }^{29}$, while in Latvia they owned $48.12 \%{ }^{30}$. In this respect Latvia and Estonia could be compared only with Hungary. The average area of estate land in Estonia was 2,113 ha ${ }^{31}$, in Latvia - even 2,507 $\mathrm{ha}^{32}$. So the extent of landlord holdings in Lithuania was nearly half the size, and the estates five or six times smaller than those of the Northern neighbours ${ }^{33}$.

Despite this fact, the agrarian issue in Lithuania took a very sharp character. Accurate data concerning land distribution are not extant, yet it is assumed that in 1919 peasant farms covered around $2,932,000$ ha, or $55.5 \%$ of total land ${ }^{34}$. Lithuanian peasant farms were

${ }^{25}$ L. Truska, "Burżuazyjna reforma agrarna 1922 r. na Litwie", Roczniki dziejów społecznych i gospodarczych, XXXIX, 1978, 112.

${ }^{26} \mathrm{~J}$. Ciepielewski, op. cit., 15.

${ }^{27}$ S. Cambel, Slovenska agrama otazka 1944-1948: O dvoch polohach agramej revolucie na Slovesku, $v$ Ceskych krajinach a problém generalnej pozemkovej reformy, Bratislava, 1972, 8-11; W. Góra, op. cit., 40.

${ }^{28} \mathrm{~A}$. Rimka, Stambusis ir smulkusis žemès ūkis nuosavybès ir bendrojo valdymo santykiais, Kaunas, 1920, Priedai, 12.

${ }^{29}$ Eesti pōllumajandus. 3, 1928, 3, 8.

${ }^{30}$ M.Skujeneeks, Latvijā: Zeme un eedzìvotajï., 3, Rīga, 1927, 383; Ë.Mūrnieks, Latvijas kolhozu zemnieciba: Sociālais raksturojums, struktrūra un attīstïbas tendences, Riga, 1975, 51.

${ }^{31}$ R. Antons, op. cit., 19.

${ }^{32}$ M. Skujeneeks, op. cit., 384, 432, 434; A. Svikis, op. cit., 10.

${ }^{33}$ In Estonia and Latvia there really existed huge estates which could be compared only to, perhaps, Hungarian, Czechoslovakian or Polish gentry. For example, in Estonia till 1919 there were 8 estates with domain over 30,000 ha. In Latvia the acreage of Dundaga estate was 69,900 ha, Pope - 50,900 ha, Vilaki - 49,200 ha. However, it is known that in Hungary duke P.Ester-Esterhazy family owned 238,000 ha (Pushkash, Bor'ba, 24), The Schwarzenberg family in Czechoslovakia owned almost 248,000 ha. (Gora, Reformy agrame, 42). Attention should be paid that these figures reflect the area of total domains and not of separate estates. Estonian and Latvian landlords often also owned more than one estate.

${ }^{34}$ Calculated on the basis: Lietuvos žemès ūkio reforma, Kaunas, 1922, 8-9; Visuotinis Lietuvos žemés ükio surašymas [ VLŽŪS], I, Kaunas, 1931, 18. According to Truska in $1905-1909$ peasants owned $2,726,000$ ha or $51.6 \%$ of the total area of lands ( $\mathrm{L}$. Truska, op. cit., 101). 
smaller than in other Baltic states. In 1913 the average area of a peasant farm in Lithuania was $15.2 \mathrm{ha}^{35}$, in Latvia - $21.0 \mathrm{ha}^{36}$, in Estonia $29.4 \mathrm{ha}^{37}$. Even considering the higher quality of land in Lithuania, the difference is striking ${ }^{38}$.

Landless peasants comprised around $21 \%$ of the whole Lithuanian agricultural population. Small peasants and the owners of extremely small land plots made up around $25 \%$. The proportion of landowners and their families was as little as $1.1 \%$ of rural dwellers ${ }^{39}$. Therefore land distribution inconsistencies and social injustice, although smaller than in Latvia and Estonia, were obvious.

Under such circumstances the only way that the authorities could expect to win themselves the support of the broader mass of peasants and to consolidate the state was to distribute smaller or bigger sections of estate owned land to the land-hungry landless peasants and those with very little land. Moreover, the new Lithuanian state itself had been established by landless peasants or those with little land, whom the government, which had once rallied them to the fight, had already made promises of land.

In Lithuania, landlords had long been polonized, and in addition were usually ant-Lithuanian and their pro-Polish orientation was regarded as dangerous to the Lithuanian state. The aim of those who had created the new Lithuania was at least at the outset to eliminate the landowner class completely while it was a strong political and economic force ${ }^{40}$. Furthermore, most of the new government officials were of peasant origin, and such a commitment was in total conformity with popular anti-landlord opinions as well as with the nationalist ambitions and economic goals of the very wear, newly-formed Lithuanian middle classes.

Another aspect of the necessity for reform is connected with economic considerations. The latter have much in common with the partition of villages into home-stead which is often regarded as an integral or even the most important part of land reform, as well as with land expropriation and partial re-distribution to peasants, - that is land reform in the narrow sense.

After the war Lithuanian agriculture remained badly damaged. The big farms - estates were the worst hit. Many landowners had abandoned their farms. $31 \%-35 \%$ of arable estate land lay fallow

${ }^{35}$ Calculated on the basis: Lietuvos žemès ūkis ir žemés reforma, 9; M. Gregorauskas, Tarybu Lietuvos žemès ükis: 1940-1960, Vilnius,1960, 67.

${ }^{36}$ Calculated on the basis: Latvijas PSR vêsture, 3, 1959, 209.

${ }^{37}$ Calculated on the basis: Eesti pollumajandus, 3, 1928, 8, 11-15.

${ }^{38}$ There is no sense to compare directly the acreage of Lithuanian farms with Hungarian, Bulgarian or Romanian farms which were formally by far smaller but had different farming conditions. If only with Polish in which in 1921 the average acreage of peasants farms was hardly over 5 ha (J. Ciepielewski, op. cit., 14).

${ }^{39} \mathrm{Calculated}$ on the basis: Lietuvos žemés ūkis ir žemés reforma, 9; A. Rimka, op. cit., Priedai, 5-6.

${ }^{40} \mathrm{~J}$. Krikščiūnas, Lietuvos žemès ūkis 1918-1938 m., Lietuva 1918-1938, Kaunas, 1990, 125. 
(in small farms - only $12 \% \ldots 13 \%$ ), with most of the farming and residential buildings destroyed or burnt down. Part of the arable estate land was cultivated, if at all, by petty leaseholders. Already before the war a great number of landlords had fallen into debt, and during the war their capital ran out completely, so that there were no means for rebuilding the estates ${ }^{41}$.

Those who set down the country's agrarian policy had every reason to believe that on a small farm where the decisive role belonged to the efforts of the owner and his family members, production could be resumed more rapidly than on estates where more capital was needed. Apart from this, landlords, being short of money and sensing the oncoming expropriation, did not hurry to resume production; they had already begun to sell off their land and forests. The land came into the hands of those who did not cultivate it and who made their living by means other than farming. The main aim of land purchases was to exploit inflation to acquire and later make a big profit by selling it ${ }^{42}$.

An important circumstance was that most agricultural specialists were quite properly considering the reorienting of Lithuanian agriculture in the direction of animal husbandry. Smaller farms, raise more animals per area unit, and in this sense they are more efficient than large ones, which are more suited to field cultivation, or even in animal husbandry, if the scope of production is proportionate with the number of people involved in production. Since there was no shortage of labour in Lithuanian agriculture, (conversely, there was over-supply) the splitting of farms was very beneficial in the social sense. Moreover, it also did not promise to be harmful economically ${ }^{43}$.

The idea of the land reform had long been an issue in Lithuania; true, its details were not immediately clear. Already at the Vilnius Diet of 1905, the idea was mooted that land in Lithuania should be administered by Lithuanians, that is by peasants. The question of the land reform was set more clearly at the Second Conference of the Lithuanian State which began in Kaunas on January 16, 1919. It proposed and passed a number of decrees, but the final decision was left for the Constituent Assembly.

During the election to the Constituent Assembly all democratic parties came to an agreement that the estates were to be reduced and a state land fund was established in order to re-distribute land to the farmers. The parties only debated the order in which estate land was to be expropriated and re-distributed, and the maximum size of remaining farms.

The Social Democrats suggested that large estates should be expropriated, land distributed or rented to agricultural communities

${ }^{41}$ Žemès ūkio ministerijos metraštis [ŽŪMM], XX, 1918-1938, Kaunas, 1938, 317; J. Krikščiūnas, op. cit., 125-126.

${ }^{42} Z \breve{Z} \bar{U} M$, XX, 1938, 23, 317; B.Povilait is, Lietuvos žemés ükis 1918-1940 m.: Jo raida ir pažanga, Toronto, $1988,67$.

${ }^{43} \check{Z} \bar{U} M M, X X, 1938,318$. 
and co-operatives, and that model, well-kept farms should be left at the disposal of the state. The Populists proposed a norm of 40 to 50 ha, the Christian Democrats - initially 70 ha, later - a maximum of 80 ha. The Populists, the Peasants' Union and the Social Democrats proposed that land should be distributed to peasants free of charge, while the right-wing suggested that the peasants should purchase their land by instalments.

Partial decrees on the reform issue were passed already in 1918-1919. In December 1918 the Land Reform Commission was established, freehold land rights and some other land was placed at the disposal of the state. By the decree of July 1, 1919, the Council of Lithuania decided to provide landless soldiers with up to 20 dessiatines of land, and grant soldiers who already owned small farm plots of a size to make a farm of 20 ha together with the formerlyowned area. To implement this legislation land could be taken from owners, holding more than 300 dessiatines ${ }^{44}$.

The principles of the Land Reform were finally laid down by two Constituent Assembly bills. The "Introductory Bill of Land Reform" passed on August 18, 1920, provided for the expropriation of land from private owners holding more than 70 dessiatines: of forests, in excess of 25 dess., marshes, peat-bogs, waters, freehold and leasehold as well as estates acquired from the tsarist administration on favourable terms ${ }^{45}$.

The last section of the land reform was passed at the Constituent Assembly on February 15, 1922. The Land Reform Bill passed by the Constituent Assembly on April 3 became a law. This act, called the main law, provided the expropriation of land in excess of 80 ha, allowing the former owners a norm of 80 ha of unexpropriated land. Those owners who after the confiscation of forests retained less than 80 ha, were allowed to supplement the missing land with forest. The law set down the procedure for using expropriated land and paying compensation to the former owners. It established that peasants would have to pay for the land they received, although this question was regulated in greater detail by subsequent acts ${ }^{46}$.

It ought to be said that the limit of 80 ha was not set by accident. In effect it marked the line between the farms of polonized landlords and those larger farms which at the turn of the 19th -20th centuries were acquired by rising Lithuanian peasants or the few Lithuanian intellectuals, industrialists and traders. As follows from the above material, Estonia and Latvia behaved in the same way, only more openly.

An amendment to the law passed on May 9, 1924, provided that a plot of land owned by several persons collectively should be considered one man's property (one farm); therefore such a farm was

${ }^{44} \mathrm{Ibid}, 318$.

${ }^{45}$ Ibid, 319.

${ }^{46}$ Vyriausybès žinios, 83, 03.04.1922, $\ln .721,1-6$. 
entitled to the norm of 80 ha. This meant some restriction to expropriation rules, as under the main law, in analogous cases, each nominal owner was allowed to keep 80 ha. The above-mentioned amendment nullified the changes introduced by the owners of more than 80 ha after the passing of the land bill (gifts of farm land, the preliminary partition of a farm among the farmer's heirs) ${ }^{47}$

To the regret of the radicals, a decision was again made on April 16, 1924 to leave 80 ha to each owner who before expropriation had managed to depart and was actually farming independently (and it was hard to check if the departure had been real or just formal). By this act the amendment to the land reform bill of May 9, 1924 was cancelled. Beside this, a decision was made to leave up to 80 ha also to the owners' future heirs who during the announcement of the bill were farming independently although at the moment they were not legally separated. Furthermore, the norm of 80 ha was left to those persons who had acquired farms under the privilege of the tsar administration, and whom the main law had deprived of any property ${ }^{48}$.

Somewhat later, on November 13, 1929, the Populists increased the norm of unexpropriated land to 150 ha. True, the owners whose farms had already been parcelled out before did not recover their land ${ }^{49}$. After this amendment was announced, around 1000 people owning between 80 and 150 ha were left out from the reform; they found the Populist amendment a real gift, although officially efforts were made to emphasize that this step rather facilitated the tasks of the State Treasury as it significantly reduced the sum of compensation for the confiscated estate land ${ }^{50}$. Some more changes were introduced into the reform bill, but these were insignificant.

In the Baltic States the execution of the land reform began in 1919 with the expropriation of estate forests and the distribution of land plots to former volunteers and soldiers. This was followed by the formation of state land funds. Actually this also happened in nearly all countries of Eastern and Central Europe.

It is most often indicated that the state land fund took about $7,223,000$ ha of land ${ }^{51}$, or $13.67 \%$ of Lithuanian territory. Including the forests and waterways confiscated in 1919-1920 (592,100 ha), as well as the lands belonging to the state, churches and monasteries, the Land and Peasants Banks, and some other lands, the Fund's total property was $1,301,500 \mathrm{ha}^{52}$, or $24.64 \%$ of state territory (with the exception of Vilnius and Klaipèda territories). This was really a lot. Yet in order to judge the scope of the reform objectively, it is worthwhile comparing these data with analogous data from Lithuania's neighbours and other countries.

${ }^{47}$ Ibid.,158, 09.05.1924, ln. 1118, 1.

${ }^{48}$ Ibid., 324, 16.04.1930, ln. 2218, 6-7; ŽUMMM, XX, 1938, 320.

${ }^{49}$ Vyriausybès žinios, $313,13.11 .1929, \ln .2113,4-5$.

${ }^{50} Z \bar{U} M M, X X, 1938,320$

${ }^{51}$ Ibid., 323; B. Povilaitis, op. cit., 74.

${ }^{52}$ L. Truska, op. cit., 120. 
In Lithuania the State Land Fund included all lands of those farmers who were affected by parcelling, and not only the expropriated land. In other countries, e.g. Estonia and Latvia, only the confiscated land was assigned to the state fund. But in Latvia and Estonia the state land fund covered all land belonging to the state, whereas in Lithuania, only the part intended to be used directly for reform needs. There were a number of other minor differences, but these did not matter so much.

Calculating the way it was done in Latvia and Estonia, the area of state Land Fund in Lithuania covered 1,591,400 ha, $(30.13 \%$ of the territory) ${ }^{53}$, in Latvia $-3,396,800$ ha $(51.48 \% \text { of the territory })^{54}$, in Estonia - 2,375,000 ha $(49.95 \% \text { of the territory })^{55}$. Thus the land reform in Lithuania embraced a smaller part of the total territory, and the Land Fund itself was not so large. The proportion of confiscated estate land was smaller in Lithuania $-76.68 \%$, while in Latvia it was $84.09 \%{ }^{57}$, in Estonia $98.42 \%{ }^{58}$ (in fact, given the subsequent specifications to the bill, $-94.44 \%{ }^{59}$ ). The land confiscated from churches and monasteries made up in Lithuania $12.89 \%{ }^{60}$, in Latvia - $83.52 \%{ }^{61}$, in Estonia - 88.41\% ${ }^{62}$.

During the land reform in Lithuania, land was expropriated and redistributed from 1600 owners. All in all, including the compensation for confiscated land, these farms were allowed to keep 186,600 ha or an average of 117 ha each (580 landlords could keep 150 ha each, $236-80$ ha, the remaining ones - $80-150$ ha each) ${ }^{63}$. Sub watching 1,061,000 ha of expropriated land from 1,384,000 ha owned by landlords in 1919 , we get is 322,800 ha. Therefore the proportion of land confiscated under the land reform from the estate owners is equal to $76.68 \%{ }^{64}$. Compared to Latvia and Estonia, in Lithuania the land reform bill left the landlords with more land, though the difference is insignificant.

${ }^{53}$ Calculated on the basis: ibid., 101, 120-21.

${ }^{54} \mathrm{E}$. Žagars, op. cit., 110-111.

${ }^{55}$ Eesti pollumajandu, 3, 1928, 1, 8; R. Antons, op. cit., 41, 64.

${ }^{56}$ Calculated on the basis: A. Rimka, op. cit.. Priedai, 12; L. Truska, op. cit., 101, 120121; VLŽŪS, I, 1931, 18.

${ }^{57}$ Calculated on the basis: E. Žagars, op. cit., 110-111, 134; Ē.Mūrnieks, Latvijas kolhozu zemniecība: Sociālais raksturojums, struktrüra un attīstïbas tendences, Rïga, 1975, 51 . 41,64 .

${ }^{58} \mathrm{Calculated}$ on the basis: Eesti pōllumajandus, 3, 1928, 1, 8; R. Antons, op. cit., 19,

${ }^{59}$ Calculated on the basis: Eesti pöllumajandus, 3, 1928, 1, 3, 8; R. Antons, op. cit., 19$21,40-41,63$.

${ }^{60}$ Calculated on the basis: A. Rimka, op. cit., Priedai, 12; L. Truska, op. cit., 20; Kolektivizacia krestianskikh khoziaistv Litovskoi SSR, Sb. dokumentov i materialov, Vilnius, 1977, 27; A. Jefremenko, Agrarnye preobrazovania i nachalo socialisticheskogo stroitelstva v litovskoi derevne v 1940-1941 godakh, Vilnius, 1972, 96-97, 242.

${ }^{61}$ Calculated on the basis: Ë. Mürnieks, op. cit., 51; E. Žagars, op. cit., 110, 139.

${ }^{62}$ Calculated on the basis: Eesti pollumajandus, 3, 1928, 8; R. Antons, op. cit., 65;

H. Tildo, Nōukogude mareform Eestis, Tallinn, 1960, 47.

${ }^{63}$ L. Truska, op. cit., 109, 121.

${ }^{64}$ Ibid., 109, 112, 120-21; VLŽŪS, I, 1931, 18. 
Formally the land reform in Latvia affected 1,253 estates, among which 845 estates were allowed a norm of 50 ha, with 408 estates having 100 ha or more. The total land left amounted to 87,200 ha, thus an average of $70 \mathrm{ha}^{65}$. Yet it is necessary to take into account the land areas of unexpropriated breeding and model farms, Latgallian farmsteads ("palivarkas"), as well as the fact that not all estates were parcelled out. Of 3,173,300 ha that in 1919 were owned by landlords in Latvia, 2,668,500 ha $(84.09 \%)$ were expropriated, 504,800 ha remained ${ }^{66}$.

In Estonia under the 1919 law, estates belonging to 619 families were expropriated, leaving them with 31,100 ha, or 36 ha per estate and 50 ha per family. Of $1,965,800$ ha of land that belonged to landowners, $1,934,700(98.42 \%)$ were subject to confiscation ${ }^{67}$. But the landlords kept control of 2,727 ha of land that belonged to estate institutions. By 1923 they had recovered 105 farms $(3,599$ ha); in $1925-$ 1929 - 415 landlords obtained land plots for buildings and for industrial purposes $(71,875 \mathrm{ha})$. So in effect the landlords were left 109,300 ha, while $94.44 \%$ of landlords' land were truly expropriated ${ }^{68}$.

In Lithuania the land reform bill provided that landlords would be compensated for the expropriated land, yet the final decision was delayed. The law only indicated that compensation was to be completed over the period of 36 years ${ }^{69}$. By the decree of 1930 individual settlement with the former owners of the confiscated land was allowed. An announcement was made that the state would cover the cost of 944,600 ha, or $88 \%$ of the confiscated land. By January 1, 1939, the state had paid a compensation of $1,429,000 \mathrm{Lt}$ to 375 persons for 526,800 ha of land, yet only $20.7 \%$ had received cash, the rest having their debts written-off, or land and forest returned ${ }^{70}$. In 1939, as the state's financial situation deteriorated, compensation was halted; the state had managed to make amends just for $55.8 \%$ of the indicated area, or $50 \%$ of the total expropriated land of the landlords ${ }^{71}$. The average sum paid was $27 \mathrm{Lt}$ per ha which was 14 to 20 times cheaper than the real value of the confiscated land.

In Estonia former owners were paid an average of $26 \mathrm{Ekr}$ per ha or 6 to 9 times less than the real cost, and this compensation covered $25 \%$ of the confiscated land ${ }^{72}$. In Latvia landowners were paid for $25 \%$ of the confiscated area, and only 21 to 22 Latas per ha which is 10 to 12 times less than the real value ${ }^{73}$. True, in Estonia and Latvia

${ }^{65}$ A. Svikis, op. cit., 73.

${ }^{66} \mathrm{E}$. Mürnieks, op. cit., 51; E. Žagars, op. cit., 110-11, 134.

${ }^{67}$ Eesti pöllumajandus, 3, 1928, 1, 3, 8.

${ }^{68}$ Calculated on the basis: Eesti pöllumajandus, 3, 1928, 1, 3, 8; R. Antons, op. cit., 19$21,40-41,63$.

${ }^{60} Z \breve{U} M M, X X, 1938,371$; Vyriausybès žinios, 83, 03.04.1922, ln. 721, 5-6.

${ }^{70} Z \bar{Z} M M, X X, 1938,384-385$; L. Truska, op. cit., 113; A. Jefremenko, op. cit., 23.

${ }^{71}$ Calculated on the basis: L. Truska, op. cit., 113, 120-21.

${ }^{72}$ Die Republik Eesti, 11; Eesti pōllumajandus, 3, 1928, 4; A.Liebman, op. cit., 21; R. Antons, op. cit., 63-64.

${ }^{73}$ E. Žagars, op. cit., 110; A. Svikis, op. cit., 52, 58-59, 135 
confiscated property included not only land, but also live and dead stock and buildings. This accounts for the fact that there, in comparison with Lithuania, the sum of compensation was somewhat further from the real cost of land. However, it is obvious that in all the Baltic States compensation for expropriated land was just a demonstration of respect to the principle of private property and not true compensation for the lords.

In Lithuania the area of land, not liable to expropriation and left for landlords, although large, was just the remains of their former holdings. The landlords' possessions were reduced 15 times. 76.68\% of the landlords' lands were expropriated and the remaining part was lost by the landowners themselves (sold, pawned etc.). Before the reform they had owned around 1,384,000 ha. In 1919 this amounted to nearly $26.2 \%$ of the entire state territory. In 1940 the people of ownerserf origin retained just 91,500 ha, or nearly $1.53 \%$ of state territory ${ }^{74}$. And this was when Lithuania had already recovered the Vilnius Territory where agrarian reform was much more moderate than in "Greater" Lithuania, and the estates were less affected.

Following the nationalisation of private forests, larger water basins, peat bogs etc., the area of state land within that period increased around 2.5 times and in 1940 comprised nearly $20 \%$ of the territory $^{75}$. Around 1,300,000 ha were placed into the hands of the state, peasantry and other private owners ${ }^{76}$.

During the reform, plots of land were obtained by many landless peasants and those with little land, although not by everyone who wanted it. Land plots were allotted to 34,057 landless peasants. They were the persons who acquired the land plots of more than 2 ha, i.e. peasants, as the total of new settlers' farms was 38,747. 26,367 peasant small-holders were granted extra land. Another 12,608 plots were distributed to rural craftsmen, for the allotments of townspeople and town-dwellers, horticultural farms, and fishermen ${ }^{77}$. The number of private landowners grew to $18.4 \% ; 12.5 \%$ of peasants obtained extra land. The total increase of peasant-owned land was by 484,200 ha, or $16.5 \%{ }^{78}$. However, applications for land in 1919 were made by 39,108 landless peasants and 55,532 peasants owning very little land ${ }^{79}$. Thus land was refused to $32.6 \%$ peasants with little land and $30.2 \%$ landless peasants.

${ }^{74}$ A.Jefremenko, op. cit., 245

${ }^{75}$ Calculated on the basis: Lietuvos statistikos metraštis [LSM], XII, 1939 m., Vilnius, 1940, 93; L. Truska, op. cit., 101, 121; Kollektivizacia krestjanskikh khoziaistv, 36, 41; A. Jefremenko, op. cit., 245.

${ }^{76}$ Calculated on the basis: LSM, XII, 1939 m., 93; A. Rimka, op. cit.. Priedai, 12; Lietuvos žemès ükis iržemès reforma, 8-9, 59; Kollektivizacia krestjanskikh khoziaistv, 36, 41; A. Jefremenko, op. cit., 245.

${ }^{77}$ LSM, XII, 1939 m., 108; L. Truska, op. cit., 120-21.

${ }^{78}$ LSM, XII, 1939 m., 108; Lietuvos žemès ūkis iržemés reforma, 8-9; L. Truska, op. cit., $112,120$.

${ }^{79}$ A. Rimka, op. cit.. Priedai, 8-9. 
During the reform the number of private landowners in Latvia increased by $39.3 \%{ }^{80}$ in Estonia by even $71.4 \%{ }^{81}$. Additional land was acquired by $33.6 \%$ Estonian ${ }^{82}$ and $36.9 \%$ Latvian $^{83}$ peasants. Most leaseholders who in 1919 comprised $7.2 \%$ of the Latvian ${ }^{84}$ and $29.2 \%{ }^{85}$ of Estonian peasantry became owners of farmsteads thanks to the reform. Over the reform period the area of land owned by peasants increased in Latvia by $54.0 \%{ }^{86}$, in Estonia $-69.3 \%{ }^{87}$. True, the extreme of peasant-used land had decreased: $28.6 \%$ in Estonia ${ }^{88}$ and $37.1 \%$ in Latvia ${ }^{89}$. These figures are greater than the analogous figures in Lithuania, yet in those states too land was not given to everyone who had applied for it and was entitled to it.

In Lithuania the amount to be paid back by those who obtained land was fluctuating, depending on the quality of the land, between 18 and 252 Lt per ha. The total amount of money to be paid by the peasants within 36 years was $34 \mathrm{mln} \mathrm{Lt}$, or an average of $84 \mathrm{Lt}$ per ha which is about 6 to 7 times less than the real price of land. Just 4 mln Lt had been paid off by $1940^{90}$.

In Latvia the land reform bill set the average purchase price at 10 Latas per ha (with a maximum up to 20 Latas). So the price of land for the peasant was 20 to 27 times less than the real market value. True, in addition to the total sum there was the loan of the State Land Bank as well as other taxes related with repayment, all of which amounted to nearly 130 Latas per ha, and this was twice as cheap as the real price of land in 1937 (200 to $270 \mathrm{Ls} / \mathrm{ha}$ ). A peasant was obliged to repay the price of his land within 41 years ${ }^{91}$.

In Estonia the peasant had to pay off his land within 60 years. Together with estate buildings and stock the land redemption price amounted to nearly $100 \mathrm{mln} \mathrm{Ekr}$, i.e. about $83 \mathrm{Ekr} / \mathrm{ha}$, or around 2 to 3 times less than the real price for land at that time (in 1934 there was an average of $134 \mathrm{Ekr} / \mathrm{ha}$ with better land costing $278 \mathrm{Ekr} / \mathrm{ha})^{92}$. By

${ }^{80}$ Calculated on the basis: Latvijas PSR vēsture, III, 1959, 209; E. Žagars, op. cit., 111

${ }^{81}$ Calculated on the basis: R. Antons, op. cit., 21, 53; H. Saarniit, Eesti bolševike agraarprogrammi väljatöötamine ja propageerimine Oktoobrirevolutsiooni eel, in Töid EKP ajaloo alalt, IV, Tallinn, 1970,55.

${ }^{82}$ Calculated on the basis: H. Saarniit, op. cit., 55; F.Virma, Kodanliku Eesti maakorraldusest, Eesti Pöllumajanduse Akadeemia teaduslike tööde kogumik: Majandusteaduslikke ja ajaloo-alaseid töid, 34, Tartu, 1963, 103.

${ }^{83}$ Calculated on the basis: Latvijas PSR vēsture. III, 1959, 209; E. Žagars, op. cit., 111

${ }^{84}$ Calculated on the basis: ibid.

${ }^{85}$ Calculated on the basis: Eesti pōllumajandus, 3, 1928, 3; R. Antons, op. cit., 20-21; H. Saarniit, op. cit., 56.

${ }^{86}$ Calculated on the basis: E. Žagars, op. cit., 111; E. Mürnieks, op. cit., 51. 43.

${ }^{87}$ Calculated on the basis: Eesti póllumajandus 3, 1928, 3; R. Antons, Op. cit., 20-21,

${ }^{88}$ Calculated on the basis: R. Antons, op. cit., 21, 43.

${ }^{89}$ Calculated on the basis: Latvijas PSR vēsture, III, 1959, 209; E. Žagars, op. cit., 111.

${ }^{90} \mathrm{~L}$. Truska, op. cit., 110-11.

${ }^{91}$ Latvijas PSR vēsture. III, 1959, 212; S.Udachin, op. cit., 72.

${ }^{92}$ Eesti NSV ajalugu: (kōigi vanemast ajast tänapäevani). Teine trükk, Tallinn, 1957, 459; Eesti statistika, 5(210), 1939, 241, 245. 
1940 actual repayment totaled $32 \mathrm{mln}$ Ekr. But in Estonia, too, the peasants paid less for the land than its real cost, despite the fact during the years of the Communist regime some historians would maintain that the repayments were huge, arguing that the total budget of the Estonian state during 1939-1940 equalled just $120 \mathrm{mln} \mathrm{Ekr}{ }^{93}$.

We should note that in Latvia and Estonia the land purchase price given here also included the price for the stock and buildings part of the formerly expropriated estates that were obtained by the peasants. Therefore the repayment sums, counting per ha of the land achieved, in Latvia and in Estonia were slightly larger in comparison to Lithuania where estate buildings and stock were not subject to expropriation.

These data can be compared only very roughly with the data on the land reform in other East European countries. The point is that generally we know very little of the statistics of those countries, and they vary greatly in ways in which they are calculated. For instance, no comparison can be made directly between Lithuanian data and those provided by the Latvian and Estonian statistical services which used to be in close co-operation with the Lithuanian Central Bureau of Statistics. Yet the general view is clear.

In Hungary between 1921 and $193854.3 \%$ applications for land were satisfied, but 411,879 persons (as many as $27.15 \%$ of landowners in 1935) obtained just 505,100 ha $(5.48 \%$ of the farm land in 1935 ; av. 1.23 ha each) ${ }^{94}$. The new owners had to pay the market price for the land they received.

In Poland between 1919 and 1938 a total of 734,100 new farms were established; they acquired 2,654,000 ha of land. Compared with 1921 this resulted in the growth of peasant farms by $22.64 \%$, with their total size increasing by $15.85 \%$. The landowners possessions were cut by $20 \%$ and landed property - by $37 \%{ }^{95}$. The State Land Bank estimated the value of the re-distributed land as being three fourths of the market price in that locality over the previous three years; this was the amount that the peasants had to pay in reality ${ }^{96}$.

In Romania expropriated land totalled 6,120,000 ha (about $30 \%$ of the total farm land), including $3,998,800$ ha of cultivated land.

${ }^{93}$ V. Krinal, Agrarnye preobrazovania v Sovetskoi Estonii, Voprosy ekonomicheskoi istorii Sovetskogo mnogonatsionalnogo gosudarstva, Moskva, 1977, 145. To tell the truth, notwithstanding that historians and economists did not avoid verbal gymnastics, characteristic of those times, they did their best to objectively highlight the years of their state independence. The Estonian texts of the same author at the same time were by far "quieter" ("calmer"): V.Krinal, L.Loone, I.Soidra, Majanduslikku mötte pöhijooni kodanlikus Eestis (1920-1940), Tallinn, 1968, 10-24. Especially when you pay attention to the facts rather than words.

${ }^{94}$ Calculated on the basis: A.I. Pushkash, op. cit., 21, 135.

95 Calculated on the basis: J. Ciepielewski, op. cit., 109; M.M. Drozdowski, Społeczeństwo, Państwo, Politycy II Rzeczpospolitej, Kraków, 1972, 17, 21; W. Szulc, op. cit., 97.

${ }^{96}$ J. Ciepielewski, op. cit., 128-129. 
By January 1, 1934, 2,308,900 families (as many as 70.4\% of the total number of farms in 1930) that had a right to land, acquired around $2,205,000$ ha (11.2\% of the total farm land in 1930; av. 0.96 ha each). Peasants were obliged to pay off their land within 20 years; besides, the first payment was required to equal $20 \%$ of the value of the plot obtained $^{97}$.

In Czechoslovakia the reform affected formally 4,066,000 ha ( $29 \%$ of the country territory) but in effect the area of the expropriated and distributed land totalled $1.8 \mathrm{mln}$ ha (nearly $13 \%$ of the territory). Around $42 \%$ of landlords' possessions were confiscated, between 1919 and $1937 ; 1,786,000$ ha were distributed and sold. 634,700 peasants acquired land $(41.33 \%$ of the total number of landowners in $1930)$ to an extent of 768,200 ha $(6.44 \%$ of the total farm land in 1930). Another 2,277 persons who already owned some land bought 772,800 ha, but this was mainly forest ${ }^{98}$.

In Yugoslavia the reform covered an area of approx. 2,5 mln ha excluding forests ( $10 \%$ of the territory, $23.5 \%$ of farm land in 1931). Over this period 669,100 families $(33.71 \%$ of the number of farms in 1931) obtained $2,120,500$ ha of land $(19.92 \%$ of the total farm land in 1931). The new owners had to pay for the acquired plots within 20 years $^{99}$.

In Bulgaria the total area of land, placed into the state land fund during $1920-1944$, was approx. 420,000 ha $(9.6 \%$ of the total farm land in 1934). Around 200,000 peasants (26\%) acquired 380,000 ha of land; this resulted in the increase of their land by nearly $8 \%{ }^{100}$

\section{Concluding Remarks}

Even this incomplete and undetailed review of the land reform bills, passed in the states of Eastern and Central Europe after World War I, gives us reason to believe that the trends of agrarian relationships and the reorganisation of the agrarian structure were the same all over the region, except for Germany (and, in part, Hungary).

The reform measures were most radically stated in Bulgaria and the countries of the Eastern Baltic region (excluding Finland). As to the relative quantities, the scope of the reform implementation was broadest in Latvia, Estonia and Lithuania.

Most statistical indicators of the land reform in Lithuania are smaller than those in Latvia and Estonia. These data gave ground for Lithuanian politicians, historians and agricultural specialists to make 271.

${ }^{97}$ Calculated on the basis: Istoria Romäniei ìn date, 323; W. Góra, op. cit., 23-25, 270-

${ }^{98}$ Calculated on the basis: R. Antons, op. cit., 33; W. Góra, op. cit., 23-25, 40-41.

${ }^{99}$ Calculated on the basis: S. Lovrenović, op. cit., 11, 17, 19; V.Stipetić, Agrarna reforma i kolonizacija u FNRJ godine 1945-1948, Zagreb, 1954, 441, 456-64; W. Szulc, op. cit., 8687, 97-98. 246.

${ }^{100}$ Calculated on the basis: W. Gorra, op. cit., 16; Ikonomika na B'lgarija, I, 533; II, 
continuous claims since the very start of the reform that the rate of the reform in Lithuania was slower than in Latvia and Estonia, and that landlords were treated more mildly there. After 1940, this was normally viewed as "unwillingness" and "inability" to make more radical progress. After 1988 it is more and more often seen as having been "unavoidable benefit" again. On reconsideration, such statements are subject to doubt. All the basic land reform measures, notwithstanding differences in their formulation, were identical in the three states. The rates were the same. And the statistical data can be misleading ${ }^{101}$.

${ }^{101} \mathrm{~A}$ simple example. Imagine that estates owning over 100 ha were expropriated. If the average acreage of estates is 400 only $75 \%$ is expropriated. Can it be said that in the second case the measures taken are more moderate? 